\title{
Children and Religion in the Public Square: "Too Dangerous and Too Safe, Too Difficult and Too Silly"
}

\author{
Bonnie J. Miller-McLemore / Vanderbilt University
}

Children and religion have not fared well in the public realm in either modernity or postmodernity. In modernity, both were banished. Modern intellectuals pronounced the subject of children "at once too dangerous and too safe, too difficult and too silly," in art historian Anne Higonnet's words, "good only for second-rate minds and perhaps for women." So children disappeared from art history and lots of other scholarly subjects. Modern intellectuals regarded religion with similar suspicion. In postmodernity, marketers, politicians, and academics ushered children back into view, but, more often than not, they have used them to promote some other religious or ideological agenda.

Scholars in religion have offered little help in all this shuffling and violation. So far they have not said much about the misuse of children for other ends, except in the acute case of sexual abuse. Over the last century, the subject of children has held minimal interest and value in the religious academy-until quite recently.

In this article, I attempt to put the subject of children back on the table. I trace some of the characteristics of their public and intellectual neglect and exploitation and then offer an initial framework for reintroducing them into theological studies. The subject matter of children, I argue, challenges the usual division between biblical, historical, systematic, and practical theology. Its reintroduction into academic study requires fresh rubrics that cross over and work between these categories. I begin by examining the characterization of children in some of the current debates before turning to their (mis)representation

\footnotetext{
${ }^{1}$ Anne Higonnet, Pictures of Innocence: The History and Crisis of Ideal Childhood (New York: Thames \& Hudson, 1998), 13-14.

(C) 2006 by The University of Chicago. All rights reserved.

$0022-4189 / 2006 / 8603-0003 \$ 10.00$
} 


\section{The Journal of Religion}

in twentieth-century theology and to the contribution of a practical feminist theology in offering a fuller understanding.

I attempt, it bears noting, neither an exhaustive portrait of the public discussion of children nor an exacting outline for their inclusion within the larger realm of theology. Nonetheless, such tasks deserve extended attention, for the stakes are relatively high: in many discussions of children, as my underlying argument will show, children themselves slip into the background. The very nature of children and childhood makes it incredibly hard to keep children as the central subject and to avoid using children to promote some other purpose. My larger aim, therefore, is to invite richer public conversation that moves beyond my own observations and suggestions to incorporate both children and religion more carefully and more fully. ${ }^{2}$ Raising children is one of the most highly charged moral and religious tasks of human life. Moreover, it has extensive consequence for the public domain. Across the political spectrum, spokespersons express growing concern about children. At the same time, on a personal level many people experience parenthood as a vocation under siege; many feel particularly unprepared for the task of children's formation, regardless of class, race, or religious tradition.

\section{THE NARROW CONCEPTION OF CHILDREN IN PUBLIC DEBATES}

Contemporary debates about children have had a strikingly narrow focus. Among the many important concerns, such as welfare reform, education, foster care, and consumerism, public discussion often gravitates back toward two issues-the controversy over the impact of day care and the reinstitutionalization of marriage as the best solution to the decline in child welfare. The latter and more recent discussion often begins with a slate of all the indices of why "our children are in

\footnotetext{
${ }^{2}$ This article was presented as a lecture at a conference in honor of Don S. Browning, "Norm and Description: Their Relation in Practical Theology, Ethics, and the Social Science," at the University of Chicago Divinity School in April 2003. It unites two themes that reflect his contribution to the study of religion: investment in the public dimension of practical and pastoral theology and interest in the subject of the family. The lecture was part of larger project, now published, aimed at reconstructing contemporary portrayals of children, Let the Children Come: Reimagining Childhood from a Christian Perspective (San Francisco: Jossey-Bass, 2003). I anticipate but do not make reference to publications on children that have appeared in theological studies in the past two years since the lecture. There has been a wonderful flurry of activity. To name a few of the recent publications: J. Bradley Wigger, The Power of God at Home: Nurturing Our Children in Love and Grace (San Francisco: Jossey-Bass, 2003); David H. Jensen, Graced Vulnerability: A Theology of Childhood (Cleveland: Pilgrim, 2005); Joyce Ann Mercer, Welcoming Children: A Practical Theology of Childhood (St. Louis: Chalice, 2005); and Kristin Herzog, Children and Our Global Future (Cleveland: Pilgrim, 2005).
} 


\section{Children and Religion}

trouble," from low standardized test scores to increased poverty and suicide to high homicide rates among fifteen- to twenty-four-year-old males. Such statistics are cause for grave concern. However, many neoliberal spokespersons use these data as reason to rally around marriage.

A three-part argument, first articulated by sociologist Barbara D. Whitehead, has become a mantra of the marriage movement. It begins with these words: "Divorce and out-of-wedlock childbirth are transforming the lives of American children." Such children, it continues, "do worse than children in intact families on several measures of wellbeing." She details the problems created by parents who pursue their own interests and by stepparents who create additional risks and then identifies the solution: the promotion of the intact, two-parent family. She, along with other prominent educators and politicians on the Council on Families in America at the New York-based Institute for American Values, issued a report on marriage in 1995 whose executive summary promoted the same three-part case. ${ }^{4}$ The divorce revolution has failed; the failure has created terrible hardships for children; time has come to rebuild a family culture of enduring marital relationships.

Outspoken critics on the progressive side take offense at this interpretation. Social scientists from a range of respected universities dash off editorials of their own, naming what they see as the real problems before us. ${ }^{5}$ They organized an alternative Washington, DC-based think tank, the Council on Contemporary Families, whose initial mission was to promote the strength and welfare of all families. ${ }^{6}$ Members of the council's original organizing committee Judith Stacey, Arlene Skolnick, and Stacey Rosencrantz, as well as political philosopher Iris Young, worry about a monocausal analysis that blames self-centered mothers and fatherless families as the root cause of crime, poverty, violence, and drug abuse. Of greater concern in children's well-being, in their opinion, are economic and social factors, including corporate greed, low wages for women, losses in real earnings and breadwinner jobs, high-level marital conflict, and decline in social resources. Poverty and school dropouts are seen as much a cause of early childbearing as a result. Poverty, ethnicity, and many other factors shape the "plural

\footnotetext{
${ }^{3}$ Barbara Dafoe Whitehead, "Dan Quayle Was Right," Atlantic Monthly, April 1993, 47; see also her The Divorce Culture: Rethinking Our Commitments to Marriage and Family (New York: Vintage Books, 1998).

${ }^{4}$ Council on Families in America, Marriage in America: A Report to the Nation (New York: Institution for American Values, 1995), 1.

${ }^{5}$ See, e.g., Arlene Skolnick and Stacey Rosencrantz, "The New Crusade for the Old Family," The American Prospect, Summer 1994, 59-65; and Judith Stacey, "Dan Quayle's Revenge: The New Family Values Crusaders," The Nation, July 25/August 1, 1994, 119-22.

${ }^{6}$ See http://www.contemporaryfamilies.org/.
} 


\section{The Journal of Religion}

childbearing cultures" that characterize U.S. society. ${ }^{7}$ This alternative view has developed its own slogans: many factors contribute to family stress, and simplistic diagnoses are problematic, if not racist, classist, sexist, and heterosexist; alternative families should not be stigmatized; and all families should be valued and supported, no matter their form.

This controversy borrows energy from another earlier, equally divisive issue-what editorialist Ellen Goodman dubs the "Thirty Year War" over child care. ${ }^{8}$ Study after study on the impact of institutional care has been done, without completely conclusive results. Debate arose once again around the April 2001 results of the National Institute of Child Health and Human Development's ten-year, ten-city study of over 1,100 preschool children, the most comprehensive study of early child care conducted to date in the United States. Some people interpreted the finding that 17 percent of preschoolers in more than thirty hours of child care are highly aggressive in kindergarten as confirmation that mothers should stay home with their children. This was, in the words of one of the chief investigators, Jay Belsky, the "moral of the story." Other people contended that this conclusion overlooks other interesting results, such as the increased language and thinking skills of children in child care. More generally, the assertion that mothers should stay home distorts evidence that on the whole children in quality day care fare well and that two-income families are happier, healthier, and better off. ${ }^{10}$

These debates are uncannily reminiscent of common household arguments among spouses and partners over who is doing more housework. In such arguments, a detailed accounting of respective workloads does not address the deeper problems. Both parties are usually doing more than either can handle and exaggerate their individual view to make a point. In the immediate sense, each person simply wants to be heard. Ultimately, however, what is needed is some greater sustaining vision about what children really need and what faithful parenting looks like in such a context.

Analogously, both sides in the cultural child-related debates overstate their case. Advocates for the intact family and stay-at-home mothers

\footnotetext{
${ }^{7}$ Iris Marion Young, "Making Single Motherhood Normal," Dissent (Winter 1994): 91. See also Paul Amato and Alan Booth, A Generation at Risk: Growing Up in an Era of Family Upheaval (Cambridge, MA: Harvard University Press, 1997); Sara McLanahan and Gary Sandefur, Growing Up with a Single Parent (Cambridge, MA: Harvard University Press, 1994).

${ }^{8}$ Ellen Goodman, "She's Up on the Tight Wire," Tennessean, April 27, 2001.

${ }^{9}$ Jay Belsky, cited by Goodman, "She's Up on the Tight Wire."

${ }^{10}$ Rosalind C. Barnett and Caryl Rivers, She Works, He Works: How Two-Income Families Are Happier, Healthier, and Better Off (New York: HarperCollins, 1996).
} 


\section{Children and Religion}

tend to sound moralistic and provincial; supporters of diversity and day care sound amoral and negligent. At the same time, both sides have merit. Adults have made selfish decisions about marriage and paid work that ignore children's well-being. Sustaining marriage for children's sake needs to be taken more seriously by society at large. Children during their first few years of life benefit from stable parental care and the steadfast attention of two parents or, indeed, of as many adult friends and relatives as the children can muster. But young children also benefit from interactions with other caregivers and peers when day care is well run and kept within reasonable limits. A lone parent with sole responsibility for children, still usually the mother, is not the only or even the best way to raise children. Nor should political policy mandate that mothers on welfare leave their children to work while political ideology urge middle-income mothers to stay home. Multiple factors besides failed marriage and institutional day care feed the frenzy around adequate care of children. It is not helpful to restigmatize families that are already struggling. Lacking adequate social support and emotional and economic resources, most people are doing the best they can most of the time to care for their children.

In general, however, I am particularly troubled by a quiet change of subject in both controversies. Children's well-being does not remain at the center. These debates devolve into ideological fights over adult lifestyles that use children to support a preferred cause. Rallying for children's welfare becomes the front for other agendas, whether that of upholding a pristine vision of marriage, polishing a tarnished memory of stay-at-home mothers, or defending family diversity regardless of the costs. Serious consideration of children's real needs in a greatly changed world gets lost.

There is abundant anecdotal evidence of the difficulty of staying with child welfare problems that defy solution. In 1994, parishioners of St. James Episcopal Cathedral, two blocks from Chicago's affluent Magnificent Mile, responded to the Chicago Tribune's decision to cover the stories of all the children murdered in 1993. Teachers and children of the Sunday school erected a Lenten cross in memory of the sixty-three dead (many from families too poor for grave markers). Over the next few years, the memorial caught the public eye, moved many souls, and sparked public action. But in 1998, the weatherworn cross blew over, parts of it were moved inside, and many people simply considered other uses for the plaza. The new peace marker that now stands there, as Jule Ward and James Halstead remark, "sadly . . . says nothing of 
The Journal of Religion

the children we continue to lose to violence every day of every year." 11 People have moved on to other issues.

THE NARROW CONCEPTION OF CHRISTIANITY IN PUBLIC DISGOURSE

Equally troubling, efforts to sustain public discussion of children typically neglect religion. A few years ago, two books attempted to move the public discussion beyond the problems of divorce and day care. Children face serious hurdles, as Sylvia Hewlett and Cornel West observe in The War against Parents, not because "parents are less devoted than they used to be" or "love their children less" but because "the whole world is pitted against them." ${ }^{12}$ In a similar book, The Assault on Parenthood, Dana Mack admits that despite her conservative views about marriage, in "our eagerness to blame single parenthood and divorce for the contemporary crisis of children," we overlook cultural perils. ${ }^{13}$ Even though the authors of the two books write from divergent political positions, there is agreement about the problems of a poisonous popular culture. Hewlett and West want better governmental support for working parents, while Mack wants the chance for women to return home. But they both see cultural forces, such as popular psychology and its so-called parent bashing or the entertainment industry and its indiscriminant promotion of sex and violence, as waging a silent war against parents.

Their respective solutions are ultimately unsatisfying however, because of their limited understanding of culture and religion. Crammed with statistics, news items, and personal stories detailing the many facets of a family-hating culture, both books offer a common blueprint for policy change as their primary answer-tax relief, workplace changes, legal support, and media and educational reform. Certainly such renewed rights and social reforms are needed. But lacking in these otherwise scrutinizing investigations is adequate exploration of religion as an essential component of culture.

Hewlett and West, for example, argue that the "key to the future" is precisely the "creation of a new political and cultural environment." ${ }^{14}$

\footnotetext{
${ }^{11}$ James Halstead and Jule D. Ward, "When Children Are Killed, What Do We Do? One Community's Response," in Suffer the Little Children: Urban Violence and Sacred Space, ed. Kay A. Read and Isabel Wollaston (Edgbaston: University of Birmingham Press, 2001), 50.

${ }^{12}$ Sylvia Ann Hewlett and Cornel West, The War against Parents: What We Can Do for America's Beleaguered Moms and Dads (New York: Houghton Mifflin, 1998), xiii.

${ }^{13}$ Dana Mack, The Assault on Parenthood: How Our Culture Undermines the Family (New York: Simon \& Schuster, 1997), 16.

${ }^{14}$ Hewlett and West, The War against Parents, 25.
} 


\section{Children and Religion}

Yet it is hard to imagine creating new public norms or challenging a predominant public morality of materialism and big business without addressing moral and religious traditions and beliefs. Attempting the kind of cultural overhaul they desire in the value of children and the practice of parenting will not get far without more careful attention to one of the most powerful culture-shaping institutions. Many social scientists, public intellectuals, and popular writers call for just such a cultural change of heart without grasping the critical role that religion might play. This is especially surprising among spokespersons familiar with religious knowledge and symbols, such as West, where one might anticipate engagement with religion. Mack points to the largely untapped resources of religious congregations. But she ridicules important efforts to criticize and reform Christian and Jewish religious traditions, such as questions about religion's support of the patriarchal family and the idealization of self-sacrifice.

Generally speaking, however, people seldom expect religion to inform nonmembers or the wider society on matters related to parenting and children. With modernity's reliance on science and technology in the twentieth century, both religion and children became private matters. Modern pretensions about secularization and technological progress divested society of the "three most ancient and most powerful concomitants of the sacred-mystery, miracle, and magic," not coincidentally elements that childbirth evokes and that children have less difficulty appreciating than adults. ${ }^{15}$ Dismissal of religion goes hand in hand with the dismissal of children from public view and with the devaluing of their care as an essential cultural and religious activity.

In the ideal modern scientific world, real adults should get over religious confession just as they should get beyond childhood and far away from those who care for children. Religious belief, children, care of children, and motherhood-all these fall below the ambitions of the smart-thinking mature adult. For many reasons, people today both within and beyond religious communities seldom see religion as a credible resource for ways to understand or care for children. If there is a publicly recognized religious voice on rearing children, it is the limited voice of James Dobson and the powerful conservative conglomerate, Focus on the Family.

\footnotetext{
${ }^{15}$ Peter L. Berger, The Sacred Canopy: Elements in a Sociological Theory of Religion (Garden City, NY: Doubleday, 1967), 108.
} 
The Journal of Religion

THE NARROW CONCEPTION OF CHILDREN IN CONTEMPORARY CHRISTIANITY

Theology mirrors these problems in a paradigmatic and problematic way. "Real" theology in the last century has been extremely adult centered. The primary subject is the mature adult. It is not an exaggeration to say that after Horace Bushnell, well known for his mid-nineteenth-century theology of childhood, the door slammed shut on children as a respectable topic. During a panel on the child and moral agency at the Society of Christian Ethics several years ago, theological ethicist Cristina Traina voiced this concern. Looking back over recent and distant Christian history, she observed, "Typically children's moral agency is an afterthought, a topic introduced to complete a theological system, and so must be forced into a script written for a universal history of salvation, usually with adults in mind." What would theological discourse look like, she asks, if "reflection on sin, salvation, and moral agency began rather than ended with childhood?" 16

Although Traina speaks here about the entire Christian corpus, the problem is most acute for contemporary theology. The volume behind this panel, The Child in Christian Thought, edited by Marcia Bunge, reveals that premodern Christian theologians sometimes paid surprising attention to children. In the last century, however, the topic of children, like women's work, has been, in Bunge's words, "somehow 'beneath' the job of the systematic theologians."17 Thinking about children has been a bit like the housework of the theological school: no one wants to do it. Many men in the field of religion do not regard children as a credible subject because of their distance from domestic care, and many women have not taken up the topic because of their proximity to them and their sometimes onerous immersion in daily care. Like the teaching of children in congregations, the subject has been pushed off to the academic wings, surfacing mostly in religious education and pastoral care.

There are notable exceptions, but even these exceptions reveal problems in the assumptions about children left in the wake of modernity. Mid-twentieth-century Catholic theologian Karl Rahner devoted a significant essay to children in the 1960s. He invokes a call to prize children and childhood as having "unsurpassable value," particularly for the Christian life. Childhood is "infinite openness," such that only the

\footnotetext{
${ }^{16}$ Cristina Traina, "Concluding Remarks" for a panel on "The Child and Moral Agency," Society of Christian Ethics, Washington, DC, January 8, 2000.

${ }^{17}$ Marcia J. Bunge, introduction to her The Child in Christian Thought (Grand Rapids, MI: Eerdmans, 2000), 4 n. 12.
} 


\section{Children and Religion}

person who "becomes that child which he only begins to be in his own childhood" attains participation in "God's interior life." 18 But he frames his remarks by making clear that, although he will address ways to think about childhood, reflection on how people should teach or raise children "cannot be the aim of a theologian." He does not explain exactly why this is the case. But he confirms Bunge's suspicion that this is beneath the job of the systematic theologian who must instead consider "what the divinely revealed word has to say about childhood." The first line of the essay itself begins with this disclaimer: "Our purpose in offering a few ideas on the theology of childhood at this point is not, in any direct sense, to be of assistance to those who, in some way or other, whether as parents or teachers, are engaging in looking after children." ${ }^{\prime 19}$

More recently, in a 2000 issue of Theology Today devoted to the topic of children, Jürgen Moltmann identifies children as "metaphors of hope." To his credit, he begins by sketching three different angles from which to understand children-as concerned parents and teachers, as children themselves, and as adults recalling our childhood. Moreover, Jewish confidence in children as gifts and Christian faith in the Messiah as redeemer free us from worshiping our own children and even from the obligation of childbearing itself. Every child brings the "light of hope" into the world and offers a "chance" for the "reign of peace." ${ }^{20}$ Yet Moltmann, in using the idea of child as "metaphor" as his primary phrase and argument, suggests that we see children figuratively as pointing to something else rather than as embodied persons themselves. Children are "metaphors of our hopes, of that which we want, wish for and expect"; they are also "metaphors of God's hope for us: God wants us, expects us, and welcomes us." ${ }^{21}$ Moltmann's own description of children throughout the essay holds them at a distance and neglects their many immediate and complex needs in and of themselves.

British theologian Adrian Thatcher also includes children as prime subjects. He makes the bold move of speaking out for their liberation. Children in particular need protection from a world largely designed about adult desire, particularly as manifest in choices about divorce

\footnotetext{
${ }^{18}$ Karl Rahner, "Ideas for a Theology of Childhood," in his Theological Investigations (London: Darton, Longman \& Todd, 1971), 8:48, 50.

${ }^{19}$ Ibid., 33. Rahner's thoughts on children are still valuable. See "'Infinite Openness to the Infinite': Karl Rahner's Contribution to Modern Catholic Thought on the Child," in The Child in Christian Thought, ed. Marcia J. Bunge (Grand Rapids, MI: Eerdmans, 2000), 406-45.

${ }^{20}$ Jürgen Moltmann, "Child and Childhood as Metaphors of Hope," Theology Today 56 (January 2000): 601 .

${ }^{21}$ Ibid., 603.
} 
The Journal of Religion

and the suffering it causes children. But, as this implies, his chief concern in putting children first is to claim their centrality within a redefined and reinvigorated Christian marriage, his primary project. ${ }^{22} \mathrm{He}$ criticizes inordinate maternal self-sacrifice and calls for greater equality between mothers and fathers-important contributions in themselves-but says remarkably little about actually living with and rearing children. Children are secondary to his aim of reestablishing the sanctity of marriage as an institution and children as one of the "goods" within it. Children witness God's blessing on the marriage and express marital love.

Process theologian Douglas Sturm also makes a strong case for the liberation of children. The adult-child relationship, he contends, exemplifies one of the last strongholds of domination, parallel to masterslave and male-female relationships of the past, and hence constitutes a final frontier for liberation theology. Children number "among the most vulnerable and most victimized of peoples." ${ }^{23}$ Their struggles extend beyond those identified by Thatcher to include fallout from technology; violence; worldwide poverty; moral confusion about racism, materialism, and corporate greed; and exploitation through child labor, prostitution, adoption trafficking, and pornography. Children deserve greater recognition within a human community that promises, in his words, "the mutual self-development of all participants." ${ }^{4}$ Yet, in sharp contrast to Thatcher, Sturm barely mentions marriage, parents, or families. Moreover, in his effort to support valuable steps by the United Nations to grant children equal rights to shelter, security, love, and self-determination, he skirts important differences between adults and children. He ignores how children's increasingly prolonged dependency within postmodern society, coupled with a heightened exposure to adult pressures, raises particular problems for children and their caregivers.

What about recent work in religious education, the body of scholarship many people assume offers resources on children? Although further careful investigation is needed, it is fair to say that recognized classics in Christian education, such as John Westerhoff's Will Our Children Have Faith? and James Fowler's popular Stages of Faith, are centered as much on adults as on children and family life. These and other acclaimed texts are wonderful books on faith. They are not so much

\footnotetext{
${ }^{22}$ Adrian Thatcher, Marriage after Modernity: Christian Marriage in Postmodern Times (New York: New York University Press, 1999).

${ }^{23}$ Douglas Sturm, "On the Suffering and Rights of Children: Toward a Theology of Childhood Liberation," Cross Currents, Summer 1992, 150.

${ }^{24}$ Ibid., 154.
} 


\section{Children and Religion}

books on children. They help adults who used to be children and who work with children understand stages through which adult faith passes on its way to greater maturity. They are not books on understanding childhood anew in an increasingly complex society. Although Westerhoff has other books more directly attentive to children and Will Our Children Have Faith? does an excellent job addressing the artificial, divisive location of education in the Sunday school wing, the title misleads readers into thinking he addresses children. ${ }^{25}$ His governing question is really whether the adults who care for children will have faith, certainly a worthy and important consideration but not exactly a response to the overt promise of the title. Similar to some of Fowler's work, the primary subject is more often the autonomous adult who is looking back over life to judge where one stands and where one is going as an adult in relationship to childhood. The focus is not "being children today" or "raising children in faith" but, as one of Fowler's books is titled, "becoming adults." ${ }^{26}$ Faith is strikingly disembodied or disconnected from the formative habits, practices, and rituals of families and congregations.

I am not being completely fair to the richness of these texts. Each one does make worthy contributions. I am merely trying to note how easily the child as a central subject slips into the background, just as happens in the wider public sphere, and serves as a means to some other equally important and certainly related, but still primarily adult, agenda. As early as 1985, pastoral theologian Andrew Lester had already commented on this problem. In a book on caring for children in crisis, he notes how few theological books fundamentally grapple with the realities of children. ${ }^{27}$ This theological neglect, as other pastoral theologians such as Pamela Couture, Herbert Anderson, and Don Browning have also shown, is intimately connected to a pastoral neglect of children as people with genuine needs in times of crises and in times of well-being. ${ }^{28}$ As Anderson argues, it is high time that theological "definitions of what it means to be human" incorporate childhood. ${ }^{29} \mathrm{~A}$ bolder theological inclusion of children is needed not only

${ }^{25}$ John H. Westerhoff, Will Our Children Have Faith? rev. ed. (Toronto: Morehouse, 2000). ${ }^{26}$ James W. Fowler, Stages of Faith (San Francisco: Harper \& Row, 1981), and Becoming Adult, Becoming Christian (San Francisco: Harper \& Row, 1983).

${ }^{27}$ Andrew D. Lester, Pastoral Care with Children in Crisis (Philadelphia: Westminister, 1985), $15,24$.

${ }^{28}$ Pamela D. Couture, Seeing Children, Seeing God: A Practical Theology of Children and Poverty (Nashville: Abingdon, 2000); Herbert Anderson and Susan B. W. Johnson, Regarding Children: A New Respect for Childhood and Families (Louisville, KY: Westminster John Knox, 1994); Don S. Browning and Ian Evison, "The Family Debate: A Middle Way," Christian Century, July 14-21, 1993, 712-16.

${ }^{29}$ Anderson and Johnson, Regarding Children, 20. 
The Journal of Religion

for children's sake but also for the sake of public discussion and for the sake of an academic theology that in its erudite deliberations has lost touch with the lively unpredictability of life with children.

STUDYING CHILDREN: A PRACTICAL FEMINIST THEOLOGICAL APPROACH

Making children a central theological concern challenges the generally accepted categories of study in theology-what has been called the "theological encyclopedia" or the nineteenth-century organization of the study of religion into the four self-defined areas of biblical, historical, systematic, and practical reflection. This schema goes back to Friedrick Schleiermacher's efforts to secure a home for religion in the modern European university in the nineteenth century. Many theologians who inherited this framework assigned practical theology a fairly circumscribed role. It concerned professional acts of congregational ministry as performed by either clergy or laity. As such, it was primarily the application of theoretical truths discovered in biblical, historical, and doctrinal theology to concrete church situations. Despite practical theological efforts to challenge this view in the last few decades, many theologians still bracket practical theology as peripheral to the more important theoretical work of biblical, historical, and systematic theology. ${ }^{30}$ The sheer matter of institutional and curricular organization in theological schools makes it hard not to misperceive systematic, historical, and biblical theology as the "real work" of theology and practical theology as simply the application of this work to acts of ministry.

Studying children, however, necessarily challenges these traditional categories. Taking children seriously as a theological subject requires a movement across the conventionally separate disciplines in the study of religion. It requires a movement from an exploration of dilemmas to an investigation of Christian resources back to a renewed practice. This movement includes moments of serious historical, biblical, and constructive theological exploration as part of a larger practical theological effort. In short, the best way to study moral and religious dilemmas of children and child rearing is from the perspective of practical theology fundamentally redefined.

Other practical theologians have called for such redefinition. Don

\footnotetext{
${ }^{30}$ Some systematic theologians have begun to do their own "practicing theology" but sometimes with little awareness or acknowledgment of previous efforts within practical theology. See, e.g., Miroslave Volf and Dorothy Bass, eds., Practicing Theology: Beliefs and Practices in Christian Life (Grand Rapids, MI: Eerdmans, 2002); or Delwin Brown, Sheila Greeve Davaney, and Kathryn Tanner, eds., Converging on Culture: Theologians in Dialogue with Cultural Analysis and Criticism (New York: Oxford University Press, 2001).
} 


\section{Children and Religion}

Browning has stood at the forefront, arguing that the theological encyclopedia ought to be reconceived entirely, with "fundamental practical theology" the name for the enterprise as a whole, containing within it the four submoments of descriptive, historical, systematic, and what Browning dubs "strategic practical theology." 31 In a word, a practical theology of children has the role of mediating between powerful religious symbol systems and the wider society. ${ }^{32}$ It tries to bridge the gap that sometimes arises between the efforts of systematic theologians to shape a religious worldview and the daily practices that actually form such a world. As a rule, systematic theologians are better at shaping overarching worldviews and formal doctrines than at monitoring the ways people practice their faith and actually live out these ideas on a daily basis. A practical theology of childhood takes this additional step. In dealing with religious texts, the final aim is distinct from systematic, biblical, and historical theology. The aim is to understand what is going on in order to effect change in a situation and in the theological ideas that define it. ${ }^{33}$

The particular subject matter of children requires just such an orientation toward practice and a movement across the divergent areas of study in religion. Childhood is not a purely theoretical concern, although children can certainly be studied in theory. Raising children is at heart a practice that engages and embodies a rich variety of developed and undeveloped theories. Practical theological knowledge about children therefore involves an investigation of what pastoral theologian Rodney Hunter called the "wisdom of experience" or of the thought that has developed within the practices of being raised and, in turn, raising children. He used this phrase to talk about "a form of practical knowledge" distinct from descriptive knowledge of "what is" and normative knowledge of "what ought to be." Practical knowledge tells "how to do things." But by this he did not mean technical knowledge about various skills or a means-ends instrumental reasoning. Practical knowledge accrues and matures over time and through practice and apprenticeship, or, in his words, "through a history of practical, contingent events." ${ }^{34}$ Reimagining childhood then takes the investiga-

\footnotetext{
${ }^{31}$ Don S. Browning, A Fundamental Practical Theology: Descriptive and Strategic Proposals (Minneapolis: Fortress, 1996).

${ }^{32}$ See David Tracy's portrait of practical theology in Blessed Rage for Order: The New Pluralism in Theology (Chicago: University of Chicago Press, 1988).

${ }^{33}$ See Elaine Graham, Transforming Practice: Pastoral Theology in an Age of Uncertainly (London and New York: Mowbray, 1996); Stephen Pattison with James Woodward, A Vision of Pastoral Theology: In Search of Words That Resurrect the Dead (Edinburgh: Contact Pastoral, 1994).

${ }^{34}$ Rodney J. Hunter, "The Future of Pastoral Theology," Pastoral Psychology 29 (Fall 1980): 67, 65 .
} 
The Journal of Religion

tor into the difficult-to-chart territory of accrued religious wisdom and the challenge of accessing its place in today's practices. Religious practices that shape children's lives are not distinct acts that follow understanding. Practice guides understanding from the beginning and is also the end toward which theory moves. ${ }^{35}$ To study children theologically therefore demands the study of the conceptual schemes and vocabulary that develop within the religious practices surrounding children and those that have arisen in history and culture at large.

Making childhood the main focus raises a few additional methodological and moral questions: How can adults genuinely understand children? How can the diversity of childhood and its social and political construction across cultures and history be appreciated? Such questions arise directly out of feminist commitment to respect for the voice and experience of the subject. Women contended for many years with claims about universal human experience that disregarded their views. Children likewise have been disregarded in claims about human experience and must be seen as actors, participants, and contributors in their own right. But one final concern and question arises out of feminist thought: How can adults, especially women and mothers, hear and represent the claims of children without losing progress made by women's movement beyond rigid roles of motherhood? Can respect for children's subjectivity come without the cost of losing women's relatively new recognition as subjects?

One way to proceed is to consider children from the perspective of "feminist maternal theology." This is certainly not the only answer nor is it an entirely sufficient answer to genuine understanding of children or inclusion of their diversity. It is simply one further step forward. Women may be enabled to hear children precisely because they have stood where children have stood, at the intersection of society's contradictory outward idealization and subtle devaluation of child care and children. Many feminist theologians have not only thought about children; they have acted as primary caregivers. A feminist maternal theology then suggests asking not only how fresh understandings of children might influence motherhood but also how contemporary experiences of mothering shape understandings of children.

As I define it elsewhere, a feminist maternal theology draws upon knowledge located within the practices of mothering as one means to

${ }^{35}$ See Robert Wuthnow's definition of practice in his own study of Growing Up Religious: Christians and Jews and Their Journeys of Faith (Boston: Beacon, 1999), xxxvi. 


\section{Children and Religion}

better understand children and other subjects. ${ }^{36}$ Philosopher Sara Ruddick, author of the widely recognized book Maternal Thinking makes the compelling observation that for too long we have remained "ignorant of the perspective, the thought that has developed from the practice of mothering." ${ }^{37}$ She does so from a feminist perspective, well aware of the destructive consequences of restricting women to the home and parenting to motherhood but also eager to reclaim distinctive knowledge gained through close involvement with the care of children. Both the passions of mothering and its cultural devaluation have distracted us. As a result, we have failed to articulate the thinking endemic to maternal practice. Drawing on Ludwig Wittgenstein, Peter Winch, and Jürgen Habermas, Ruddick claims that maternal thinking arises out of the social practice of mothering. In response to the "historical reality of a biological child in a particular social world," the mother "asks certain questions rather than others; she establishes criteria for the truth, adequacy, and relevance of proposed answers; and she cares about the findings she makes and can act on." ${ }^{38}$ In this respect, a feminist maternal perspective moves carefully past liberal feminism's critique of motherhood as a source of exploitation and on toward its potential as a site for knowledge necessary to human survival. In essence, to know more about children, we need to know more about the "conceptual scheme" or "vocabulary and logic of connections" that orders and expresses the practices of children and parents. ${ }^{39}$

Maternal thinking has already shaped pivotal insights in feminist theology. When Valerie Saiving first put forth the idea, revolutionary for its time, that sin in women does not lie in prideful self-assertion-as many men had defined it-but in self-loss and denigration, she drew heavily upon her own experience as a single mother raising a young daughter while doing graduate study in the late $1950 \mathrm{~s} .{ }^{40}$ Other equally provocative challenges to Christian conceptions of sexual ethics, the sacrificial meaning of the atonement, love as self-sacrifice, and Chris-

\footnotetext{
${ }^{36}$ Bonnie J. Miller-McLemore, Also a Mother: Work and Family as Theological Dilemma (Nashville: Abingdon, 1994), 104-5, and see also "Pondering All These Things': Mary and Motherhood," in Blessed One: Protestant Perceptions of Mary, ed. Cynthia L. Rigby and Beverly Roberts Gaventa (Louisville, KY: Westminster John Knox, 2002), 97-114.

${ }^{37}$ Sara Ruddick, "Maternal Thinking," in Mothering: Essays in Feminist Theory, ed. Joyce Treblicot (Totowa, NH: Rowman \& Allanheld, 1983), 213.

${ }^{38}$ Ibid., 214.

${ }^{39}$ Sara Ruddick, Maternal Thinking: Toward a Politics of Peace (Boston: Beacon, 1989), 24.

${ }^{40}$ Valerie Saiving, "The Human Situation: A Feminine View," Journal of Religion 40 (April 1960): 108, repr. in Womanspirit Rising: A Feminist Reader in Religion, ed. Carol P. Christ and Judith Plaskow (San Francisco: Harper \& Row, 1979).
} 


\section{The Journal of Religion}

tian vocation have evolved as a result of the proximity and intimacy between mothers and children. ${ }^{41}$

A feminist maternal theology of childhood extends four core premises of feminist thought in new directions. First, the demand to give privileged voice to the marginalized is extended to mothers and children. Second, feminist maternal theology challenges the contradictory demonization and idealization of children and women's bodies in the acts of bearing and raising children. Third, it enriches debates about theological doctrines of Christian love, sin, and grace by turning to the complex questions of love between the unequal parties of adult and child. Finally, a feminist maternal theology stretches claims for justice and liberation across differences to include children and mothers for whom the democratic principle of equality based on formal identity or sameness with the adult male simply does not work.

Modern dismissal of children as important subjects, alongside the dismissal of religion as a public resource, are unfortunate because both leave an entire spectrum of human behavior and history untouched, overlooked, and possibly misunderstood. To effect genuine cultural change in children's lives requires careful and fair exploration, critique, and revision of religion as a key culture-forming institution. Christianity, as is true for many religions, continues to shape children and to determine how people think about and act toward them more than most people realize. Religious institutions continue to provide family-related moral discourse, communities of social support and control, and frameworks of meaning "to make sense of the joys, stresses, and transitions that accompany family life," as W. Bradford Wilcox asserts. ${ }^{42}$ Religion shapes shared history and normative visions. Hence, politicians and parents alike would benefit from a richer public understanding of traditions that have shaped children and child rearing

${ }^{41}$ See Christine E. Gudorf, "Parenting, Mutual Love, and Sacrifice," in Women's Consciousness and Women's Conscience: A Reader in Feminist Ethics, ed. Barbara Hilkert Andolsen, Christine E. Gudorf, and Mary D. Pellauer (San Francisco: Harper \& Row, 1985), 175-91; Sally Purvis, "Mothers, Neighbors and Strangers: Another Look at Agape," Journal of Feminist Studies in Religion 7 (Spring 1991): 19-34; Cristina Traina, "Maternal Experience and the Boundaries of Christian Sexual Ethics," Signs: Journal of Women in Culture and Society 25 (Winter 2000): 369-405, and "Passionate Mothering: Toward an Ethic of Appropriate Parent-Child Intimacy," Annual of Christian Ethics 18 (1998): 177-96; and Cynthia L. Rigby, "Exploring Our Hesitation: Feminist Theologies and the Nurture of Children," Theology Today 56 (January 2000): 540-54.

${ }^{42}$ W. Bradford Wilcox, "For the Sake of the Children? Family-Related Discourse and Practice in the Mainline" (unpublished manuscript, "Public Role of Mainline Protestantism" project, Princeton University; Robert Wuthnow, principal investigator); portions of Wilcox's paper appear in "Mixed Messages: Churches' Witness on the Family," Christian Century, February 21, 2001, 16-19, adapted from an essay in The Quiet Hand of God: Faith-Based Activism and the Public Role of Mainline Protestantism, ed. Robert Wuthnow and John H. Evans (Berkeley: University of California Press, 2002). 


\section{Children and Religion}

through specifically religious and moral language and practices. Indeed, various religious traditions, including Christianity, have long seen children as part of the common good and, hence, a public concern. Reclaiming religion's importance in the public square involves then, in some ways, reclaiming children's public value and voice.

If the public must rethink its constructions of children and religion, a feminist practical theology is a worthy partner in such reimagining. The study of children calls for a distinctive approach in theology, one that involves both practical and feminist thought. Broadly speaking, a practical feminist theological method promotes two important agendas that would serve well to enhance public debates about children: reflection on daily life as central to theology and respect for the voices of the marginalized as a guiding norm. Reflection on children embodies the theological conviction that the divine manifests itself in the mundane and that genuine liberation must occur in the most commonplace of places-in the embodied lives of children. 